\title{
A New Biosurfactant Produced by Candida glabrata UCP 1002: Characteristics of Stability and Application in Oil Recovery
}

\author{
Juliana Moura de Luna $^{1}$, Leonie Sarubbo ${ }^{2,3}$ and Galba Maria de Campos-Takaki ${ }^{2,3 *}$ \\ ${ }^{I}$ Universidade Federal de Pernambuco; Av. Prof. Moraes Rêgo, s/n; Cidade Universitária; 50.900-000; Recife - PE \\ - Brasil. ${ }^{2,3}$ Departamento de Química; Universidade Católica de Pernambuco; Rua Nunes Machado, 42; Bloco J; \\ Térreo; Boa Vista; 50050-590; Recife - PE - Brasil
}

\begin{abstract}
The production of a new biosurfactant by Candida glabrata UCP1002 was studied to evaluate the influence of the concentration of the cotton seed oil, glucose and yeast extract. The dynamics of the growth and surfactant production were showed for all the cultivation conditions studied. The best emulsification of the n-hexadecane, quantified by the emulsifying index was observed in the medium containing $7.5 \%$ cotton seed oil, 5\% glucose and $0.3 \%$ yeast extract. The isolated biosurfactant showed a CMC of $2.5 \%$ and the surface tension at that point showed to be $31 \mathrm{mN} / \mathrm{m}$. The potential application of the biosurfactant in oil recovery from the sand, in acid and alkaline environments and over exposure to high salinity and different temperatures was demonstrated by the percentage of oil removal and by the stability of the surface tension, respectively.
\end{abstract}

Key words: Biosurfactant, Candida glabrata, surface tension, stability, cotton seed oil, oil removal

\section{INTRODUCTION}

Surfactants are amphipathic molecules, which reduce the interfacial tensions between liquids, solids and gases and confer excellent detergency, emulsifying, foaming and other versatile chemical process (Dubey and Juwarkar, 2001). Biosurfactants constitute one of the main classes of natural surfactants produced by the microrganisms, being classified in accordance with their chemical composition or microbial origin. The main classes include glycolipids, lipopeptides and lipoproteins (Ron, 2001; Hua et al., 2003). These polymers have attracted, in the last few years, considerable interest due to biodegradable nature, low toxicity and diversity of applications. The possibility of modification of the chemical structure and the physical properties of biosurfactants through genetic, biological or chemical manipulations, allows the development of products for specific necessities (Rahman et al., 2003; Queiroga et al., 2003).

The biosurfactants, despite the diversity of industrial applications, are still not widely used due to the high costs of the production associated with inefficient methods of recovery of the product and the use of expensive substrates. However, the economic problem of the production of biosurfactants can significantly be reduced through the use of alternative sources easily available and

\footnotetext{
* Author for correspondence: gmctakaki@pq.cnpq.br
} 
of low cost. The effluents of vegetable oil industries, petrochemical oil residues or the byproducts from the food industries have been extensively studied for the microbial production at an experimental scale (Mercade et al., 1993; Mercade et al., 1996; Vollbrecht et al., 1999; Deleu and Paquot, 2004).

A large number of carbon sources, such as the sugars and oils are described, as attractive substrates for the production of biosurfactants (Gallert et al., 2002). High incomes in the products have been used through the combination between a vegetable oil and carbohydrate as substrate (Zhou and Kosaric, 1993). Between yeasts, species of Candida have been widely used in the production of biosurfactants from soluble and insoluble carbon sources (Sarubbo et al., 1997; 1999; 2001). In this work, the production of a biosurfactant by Candida glabrata UCP1002 was investigated using different concentrations of cotton seed oil, glucose and yeast extract as. The surface active properties under specific environmental conditions and the application of the biopolymer in oil removal had been carried through.

\section{MATERIALS AND METHODS}

\section{Microrganism}

C. glabrata UCP 1002 was isolated from the mangrove sediments of Rio Formoso city, Pernambuco, Brazil (Gomes et al., 2000). It was kindly supplied from the culture collection of the Universidade Católica de Pernambuco (UNICAP), Brazil, maintained at $5^{\circ} \mathrm{C}$ on Yeast Mold Agar (YMA) slants containing (w/v) yeast extract $(0.3 \%)$, malt extract $(0.3 \%)$, tryptone $(0.5 \%)$, Dglucose $(1 \%)$, and agar $(5 \%)$. Transfers were done to fresh agar slants each month to maintain viability.

\section{Reagents}

N-Hexadecane was obtained from Sigma Chemical Co. (St. Louis, MO); food grade cotton seed oil was obtained from Bunge Alimentos S.A. ( $\mathrm{SC}$, Brasil). Other chemicals used were analytical grade.

\section{Inoculum preparation}

The $C$. glabrata was grown in solid medium at $27^{\circ} \mathrm{C}$ for $48-72 \mathrm{~h}$, then, a loopful of the cells were transferred to Erlenmeyer flasks of $250 \mathrm{~mL}$ containing $50 \mathrm{~mL}$ of the Yeast Mold Broth (CYM) and incubated aerobically for one day at $27^{\circ} \mathrm{C}$ on a rotary shaker $(150 \mathrm{rpm})$.

\section{Culture conditions}

The yeast was cultivated in submerged culture with shaking in a New Bruswick G-25 shaker. The medium was composed of the following components: $\mathrm{NH}_{4} \mathrm{NO}_{3}(0.1 \%), \mathrm{KH}_{2} \mathrm{PO}_{4}(0.02 \%)$, $\mathrm{MgSO}_{4} .7 \mathrm{H}_{2} \mathrm{O}(0.02 \%)$ and cotton seed oil, glucose and yeast extract in different concentrations, as described in Table 1. The $\mathrm{pH}$ was adjusted to $\mathrm{pH}$ 5.7 with $1 \mathrm{M} \mathrm{HCl}$ solution. Erlenmeyer's flasks $(1000 \mathrm{ml})$ were filled with $300 \mathrm{ml}$ of liquid medium and sterilized at $121^{\circ} \mathrm{C}$ for $20 \mathrm{~min}$. The inoculum was introduced in the amount of $10^{4}$ cells $/ \mathrm{ml}$ of the $24 \mathrm{~h}$ culture grown on CYM. The flasks were incubated at $27^{\circ} \mathrm{C}$ with shaking at 200 $\mathrm{rpm}$ for $144 \mathrm{~h}$. The $\mathrm{pH}$ of the media was not adjusted during cultivation. The efficiency of biosurfactant biosynthesis was evaluated in correlation with the doses of substrates used during the fermentation. Samples were taken every $6 \mathrm{~h}$ during the first $24 \mathrm{~h}$ and every $24 \mathrm{~h}$ until the end of cultivation period (144 hours) and analysed too biomass, monitored by cells counts on Neubauer Camera and plated on Yeast Mold Agar, $\mathrm{pH}$, and emulsification activity. Experiments were done in duplicate and results reported are the average from three independent experiments.

\section{Emulsification activity}

Emulsification activity was measured using the method described by Cooper and Goldenberg (1987), whereby $6 \mathrm{ml}$ of $\mathrm{n}$-hexadecane was added to $4 \mathrm{ml}$ of the culture broth free of cells in a graduated screwcap test tube and vortexed at high speed for $2 \mathrm{~min}$. The emulsion stability was determined after $24 \mathrm{~h}$, and the emulsification index was calculated by dividing the measured height of the emulsion layer by the mixture's total height and multiplying by 100 . 
Table 1 - Substrates concentrations utilized in the cultivation of $C$. glabrata UCP1002 in mineral medium

\begin{tabular}{cccc}
\hline \multirow{2}{*}{ Conditions } & \multicolumn{3}{c}{ Substrate concentration $(\%)$} \\
\cline { 2 - 4 } & Cotton seed oil & Glucose & Yeast extract \\
\hline A & 5.0 & - & 0.2 \\
B & 10.0 & - & 0.2 \\
C & 5.0 & 10.0 & 0.2 \\
D & 10.0 & 10.0 & 0.4 \\
E & 5.0 & - & 0.4 \\
F & 10.0 & - & 0.4 \\
G & 5.0 & 10.0 & 0.4 \\
H & 10.0 & 10.0 & 0.2 \\
I & 7.5 & 5.0 & 0.3 \\
\hline
\end{tabular}

Determination of the stability of the biosurfactant

Stability studies were done using the cell-free broth obtained by centrifuging the cultures at 5000 rpm for 20 minutes. Samples of the cell - free culture broth were maintained at 4,27 and $80^{\circ} \mathrm{C}$ to 10 minutes and cooled to room temperature, after which the surface tension was measured. To study the $\mathrm{pH}$ stability of the cell-free broth, the $\mathrm{pH}$ of the cell-free broth was adjusted to different $\mathrm{pH}$ values (2 to 12) and the surface tension was measured. The effect of $\mathrm{NaCl}$ concentrations (2 to 10\%) on the surface tension of the culture broth free of cells was also determined.

\section{Isolation of biosurfactant}

The $144 \mathrm{~h}$ culture was refrigerated for $24 \mathrm{~h}$ to solidify the remaining oil and to effect yeast settling. The culture was filtered through Whatman no. 1 filter paper and centrifuged at $10000 \mathrm{x}$ g for 15 minutes. The cell-free broth was concentrated $(500 \mathrm{ml})$ by freeze drying and extracted three times with chloroform (1:1, by vol.) in a separatory funnel at $28^{\circ} \mathrm{C}$ (Sarubbo et al. 2006).

\section{Determination of surface tension and critical micellar concentration (CMC)}

The measurement of the surface tension was carried out on the cell-free broth obtained by centrifuging the cultures at $5000 \mathrm{rpm}$ for 20 minutes by the ring method using a Sigma 70 Tensiometer (KSV Instruments LTD - Finland) at room temperature. Stabilization was allowed to occur until standard deviation of 10 successive measurements was less than $0.4 \mathrm{mN} / \mathrm{m}$. Each result was the average of 10 determinations after stabilization.

Biosurfactant production reduces the interfacial tension oil/water and the superficial tension air/water. These effects are proportional to biosurfactant concentration in dissolution until this reaches the Critical Micelle Concentration (CMC). The CMC was determined by measuring the surface tensions of dilutions of purified biosurfactant in distilled water up to a constant value of surface tension. The value of CMC was obtained from the plot of surface tension versus the logarithm of the concentration. The CMC value was determined to be $\mathrm{g} \mathrm{l}^{-1}$ of biosurfactant.

\section{Application of the biosurfactant in motor oil removal from contaminated sand}

Biosurfactant suitability for enhanced oil recovery was carried using $60 \mathrm{~g}$ of beach sand impregnated with $5 \mathrm{~mL}$ of motor oil. Fractions of $20 \mathrm{~g}$ of the contaminated sand were transferred to $250 \mathrm{~mL}$ Erlenmeyer flasks, which were submitted to the following treatments: addition of $60 \mathrm{~mL}$ distilled water (control) and addition of $60 \mathrm{~mL}$ of aqueous solution of biosurfactant at $1.5 \%$ and at the CMC ( $2.5 \%$ concentration). The samples were incubated on a rotary shaker $(150 \mathrm{rpm})$ for $24 \mathrm{~h}$ at $27^{\circ} \mathrm{C}$ and then were centrifuged at $5000 \mathrm{rpm}$ for 20 minutes for separation of the laundering solution and the sand. The amount of oil residing in the sand after the impact of biosurfactant was gravimetrically determined as the amount of material extracted from the sand by hexane (Nistchke and Pastore, 2002).

\section{RESULTS AND DISCUSSION}

\section{Kinetic growth of Candida glabrata}

Previous works have demonstrated the combination of a carbohydrate plus vegetal oil as a very interesting alternative for the production of surfactants by the yeasts (Davila et al., 1992; 
Garcia-Ochoa and Casas, 1999; Zhou and Kosaric, 1993; 1995; Sarubbo et al., 2006).

Biosurfactant production was studied in experiments by varying the initials concentrations of the cotton seed oil, glucose and yeast extract, as showen in Table 1. The change in the biomass, emulsification activity and $\mathrm{pH}$ of the cultivations with time is shown in Fig. 1.
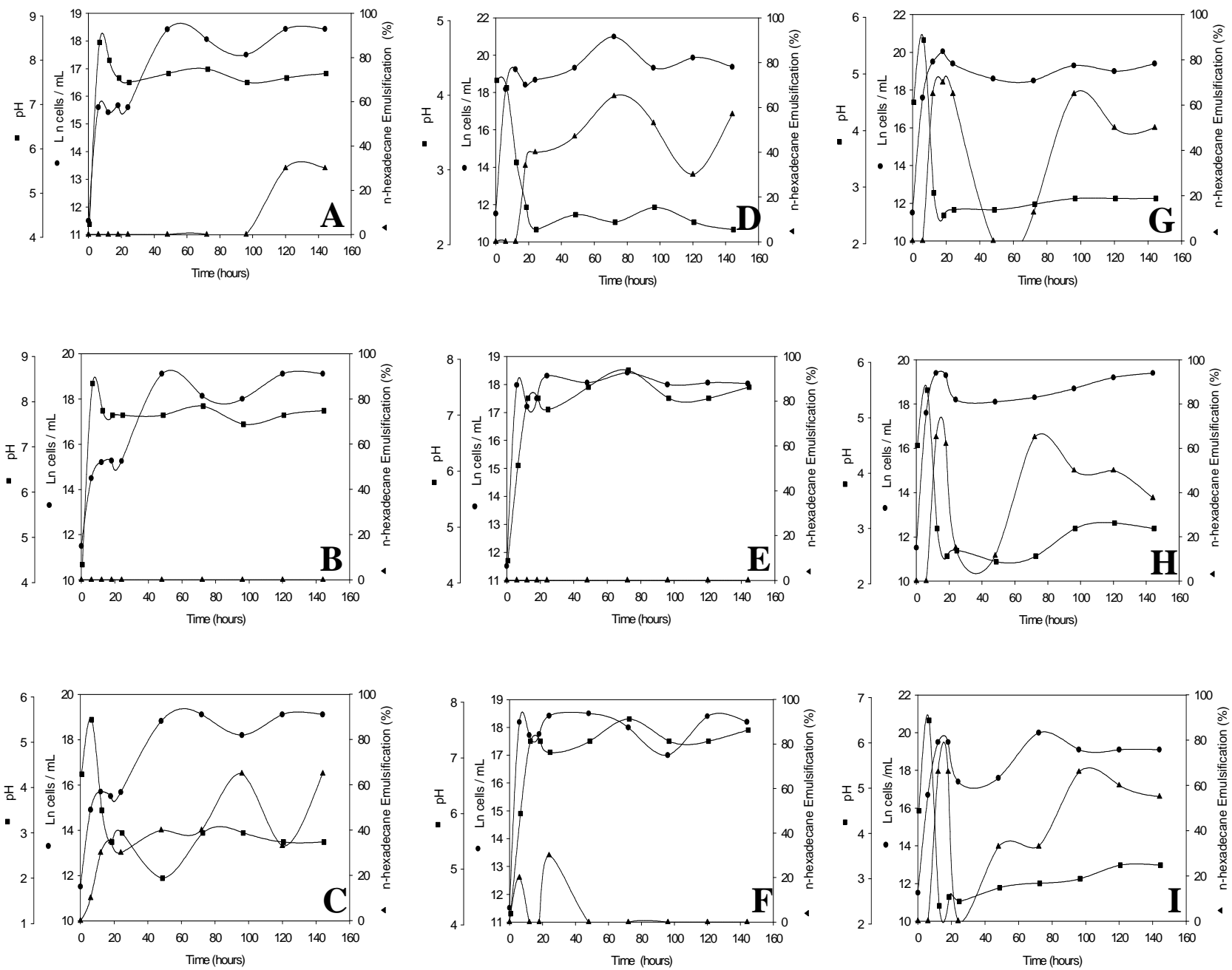

Figure 1 - Biosurfactant production by Candida glabrata grown in mineral medium supplemented with: (A) $5 \%$ cotton seed oil and $0.2 \%$ yeast extract; (B) $10 \%$ cotton seed and $0.2 \%$ yeast extract; (C) $5 \%$ cotton seed oil, $10 \%$ glucose and $0.2 \%$ yeast extract; (D) $10 \%$ cotton seed oil, $10 \%$ glucose and 0.4 $\%$ yeast extract; (E) $5 \%$ cotton seed oil and $0.4 \%$ yeast extract; (F) $10 \%$ cotton seed oil and $0.4 \%$ yeast extract; (G) 5\% cotton seed oil, $10 \%$ glucose and $0.4 \%$ yeast extract; $(\mathrm{H}) 10 \%$ cotton seed oil, $10 \%$ glucose and $0.2 \%$ yeast extract; (I) $7.5 \%$ cotton seed oil, $5 \%$ glucose and $0.3 \%$ yeast extract. Biomass produced, $\mathrm{pH}$ and emulsification activity.

The kinetics of growth of C. glabrata demonstrated a diauxic profile. The presence of glucose in the cultivation medium was a decisive factor for the acidity of the culture since with its presence there was a reduction in the $\mathrm{pH}$ (Figs. 1C, $1 \mathrm{D}, 1 \mathrm{G}, 1 \mathrm{H}$ and $1 \mathrm{I})$, which reached stable values, around 3.0, in the beginning of the stationary phase of the growth, probably due the production of metabolic organic acids. On the other hand, in the absence of glucose (Figs. 1A, 1B, 1E and 1F), an increase of the $\mathrm{pH}$ was observed in the initial hours of cultivation, which reached values close to 8.0, with stabilization around 7.0 until the end of $144 \mathrm{~h}$. The kinetics of emulsification activity 
demonstrated that $C$. glabrata was not able to emulsify the n-hexadecane indeed in the medium without glucose (Figs. 1A, 1B, 1E and 1F). In the media containing cotton seed oil and glucose (Figs. 1C, 1D, 1G 1H and 1I), peaks of emulsification activity were observed along the cultivation. The medium cultivation containing $7.5 \%$ cotton seed oil, $5 \%$ glucose and $0.3 \%$ yeast extract (Fig. 1I), presented similar results to the conditions obtained in Figs. $1 \mathrm{G}$ and $1 \mathrm{H}$, in what it referred to the emulsification of n-hexadecane.

The results obtained permitted to select the medium cultivation containing $7.5 \%$ cotton seed oil, $5 \%$ glucose and $0.3 \%$ yeast extract (Fig. 1I) as the best condition for biosurfactant production regarding the emulsification with n-hexadecane $(66 \%)$ after $96 \mathrm{~h}$ of fermentation.

\section{Properties of the selected biosurfactant}

The tests accomplished in the cell-free broth, regarding the variation of the $\mathrm{pH}$, demonstrated an effective stability of the surface tension (Fig. 2).

These results were in agreement with the surface tension values found for the biosurfactant of Nocardia sp. L-417, which remained stable in all the $\mathrm{pH}$ values tested (from 2 to 12), indicating that the variation of the $\mathrm{pH}$ didn't also have significant effect on the superficial tension (Kim et al., 2000). The surface tension of the biosurfactant produced by Bacillus subtillis was also stable under different $\mathrm{pH}$ values (Makkar and Cameotra, 1998), although the effectiveness of liposan of $C$. lipolytica as emulsifier was limited to the acid to neutral $\mathrm{pH}$ (Cirigliano and Carman, 1984).

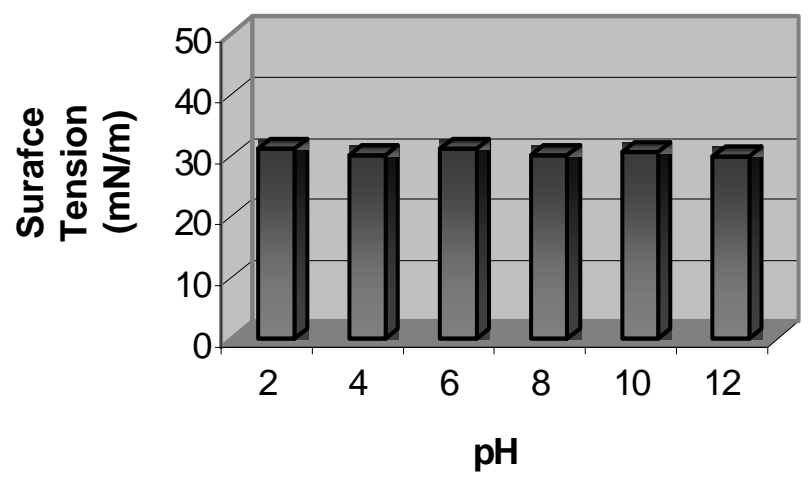

Figure 2 - Influence of $\mathrm{pH}$ on the surface tension of cell-free broth of Candida glabrata grown on mineral medium supplemented with $7.5 \%$ cotton seed oil, $5.0 \%$ glucose and $0.3 \%$ yeast extract.

The surface tension of the cell-free broth containing the biosurfactant showed to be stable, independent of the concentration of salt added (Fig. 3).

Desai and Banat (1997), reported that concentrations above $2 \%$ of $\mathrm{NaCl}$ were enough to inactivate a synthetic surfactant. Reductions were also observed in the emulsification activity of the surfactant produced by $C$. lipolytica cultivated in n-hexadecane (Cirigliano and Carman, 1984) and of the surfactant from mixed cultures cultivated in molasses (Ghurye et al., 1994).

Regarding the influence of the temperature on the surface tension of the cell-free broth containing the biosurfactant (Fig.4), it was observed that the same stable front stayed to the studied temperatures. The results obtained by Brown et al., (1991) for the biosurfactant produced by a bacterium designated as isolated 1165 showed a reduction of the surface tension in the cell-free broth when submitted to temperatures among $0 \mathrm{C}^{\mathrm{o}}$ and $4^{\circ} \mathrm{C}$, although exposure to high temperatures $\left(100\right.$ and $\left.120{ }^{\circ} \mathrm{C}\right)$ did not affect the surface tension values. On the other hand, Markkar and Cameotra (2002) observed the stability of the surface tension after the exposure of the biosurfactant produced by Bacillus subtilis at $100^{\circ} \mathrm{C}$. 


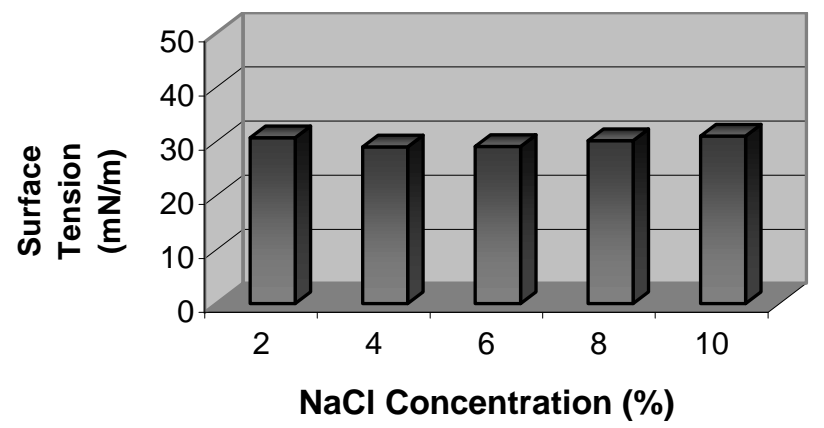

Figure 3 - Influence of different sodium chloride concentrations on the surface tension of cell-free broth of Candida glabrata grown on mineral medium supplemented with $7.5 \%$ cotton seed oil, $5.0 \%$ glucose and $0.3 \%$ yeast extract.

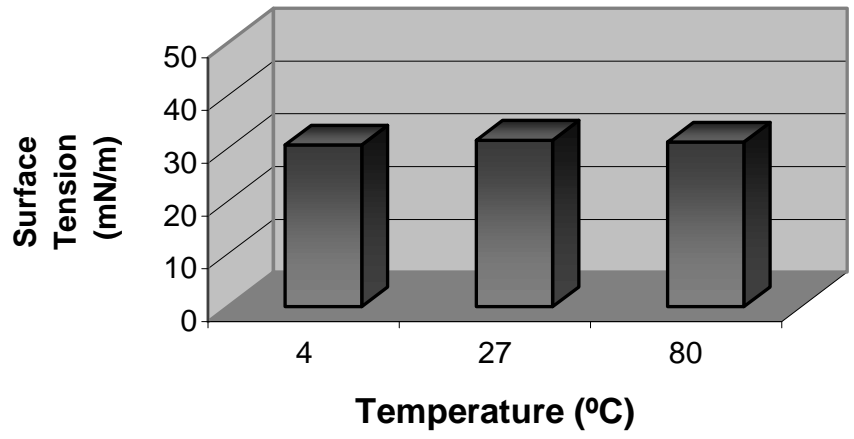

Figure 4 - Influence of temperature on the surface tension of cell-free broth of Candida glabrata grown on mineral medium supplemented with $7.5 \%$ cotton seed oil, $5.0 \%$ glucose and $0.3 \%$ yeast extract.

\footnotetext{
Surface tension and critical micellar concentration (CMC) of the biosurfactant

The presence of a surfactant reduces the surface tension air/water, which was proportional to the concentration of the biosurfactant in the solution, until it reached the CMC (Ron and Ronsenberg, 2001). As shown in Fig. 5, the CMC of the

biosurfactant produced by $C$. glabrata was of approximately $2.5 \%$ and the surface tension at that point was of $31 \mathrm{mN} / \mathrm{m}$. This tension value was similar to the values described for other potent biosurfactants produced by the yeasts cultivated in the vegetable oils plus carbohydrates as substrates (Davila et al., 1992; Marin, 1996).
} 


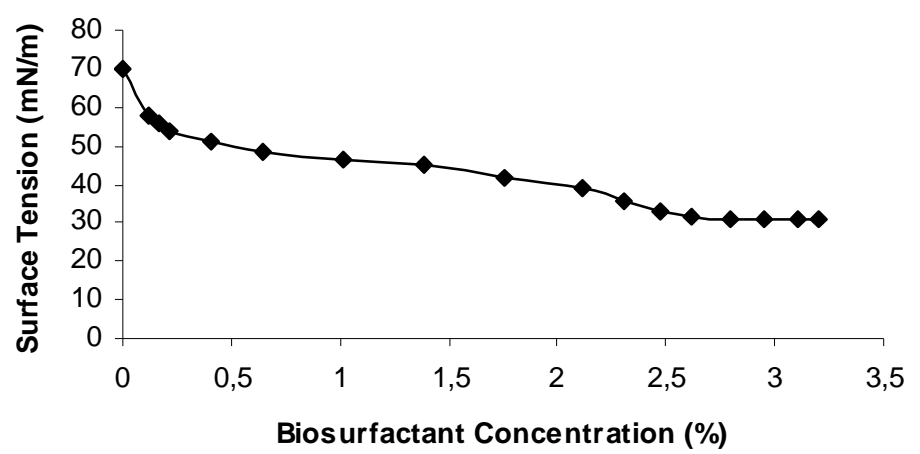

Figure 5 - Surface tension versus concentration of the isolated biosurfactant produced by Candida glabrata grown on mineral medium supplemented with $7.5 \%$ cotton seed oil, $5.0 \%$ glucose and $0.3 \%$ yeast extract.

\section{Application of the biosurfactant in the oil removal}

Table 2 describes the removal of motor oil by different concentrations of the biosurfactant.

The results obtained demonstrated that the biosurfactant solution at $2.5 \%$ concentration (at the CMC) was capable to remove $84 \%$ of the oil adsorbed in the sand, while the distilled water (control) removed $56 \%$ of the contaminated oil. Similar results were obtained by Abu-Ruwaida et al., (1991) for the cell-free broth containing a biosurfactant produced by Rhodococcus cells, which was able to recover $86 \%$ of crude residual oil adsorbed in the sand, while distilled water removed about $65 \%$ of the oil.

Cameotra and Makkar (1998) demonstrated that the biosurfactant isolated form Pseudomonas aeruginosa was able to recover $56 \%$ of the oil adsorbed to the sand contained in a column.

Table 2 - Removal of motor oil from contaminated sand by the grown on mineral medium supplemented with $7.5 \%$ cotton seed oil, $5.0 \%$ glucose and $0.3 \%$ yeast extract.

\begin{tabular}{lcc}
\hline Treatment & Residual oil (\%) & Removed oil (\%) \\
\hline $1.5 \%$ biosurfactant solution & 36.4 & 63.6 \\
$2.5 \%$ biosurfactant solution & 16 & 84 \\
Distilled water (control) & 43.7 & 56.3 \\
\hline
\end{tabular}

\section{CONCLUSIONS}

The results obtained in this work showed that the biosurfactant produced by $C$. glabrata had attractive properties as low surface tension at the $\mathrm{CMC}$, stability over a wide range of $\mathrm{pH}$ and temperature and exposure to high salinity. The ability in recovering the oil from oil-saturated sand was also demonstrated. Thus, these characteristics indicated potential use of the biosurfactant in the oil industry, especially in MEOR (microbial Enhanced Oil Recovery). Studies are in progress to scale up the growth conditions and biosurfactant production in the bioreactors.

\section{ACKNOWLEDGEMENTS}

This work was supported by Agência Financiadora de Estudos e Projetos (FINEP) and Conselho Nacional Científico e Tecnológico (CNPq), Brazil We are grateful to Núcleo de Pesquisas em Ciências Ambientais (NPCIAMB) laboratories, Universidade Católica de Pernambuco, Brazil. 


\section{RESUMO}

A produção de um novo biossurfactante por Candida glabrata UCP1002 foi inicialmente investigada com a finalidade de avaliar a influência da concentração dos substratos óleo de algodão, glicose e extrato de levedura. As cinéticas de crescimento e de produção do surfactante foram demonstradas para todas as condições de cultivo testadas. A melhor emulsificação do nhexadecano, quantificada através do índice de emulsificação foi observada na condição de cultivo contendo $7,5 \%$ de óleo de algodão, $5 \%$ de glicose e $0,3 \%$ de extrato de levedura. O biossurfactante produzido apresentou uma concentração micelar crítica de $2,5 \%$, sendo a tensão superficial nesse ponto de $31 \mathrm{mN} / \mathrm{m}$. O potencial de aplicação do biossurfactante na recuperação de óleo de areia contaminada, em condições ácidas e alcalinas, bem como sob exposição a altas salinidades e diferentes temperaturas, foram demonstrados com base no percentual de remoção do óleo e na estabilidade da tensão superficial, respectivamente.

\section{REFERENCES}

Abu-Ruwaida, A.S.; Banat, I.M.; Haditirto, S.; Salem, A. and Kadri, M. (1991), Isolation of biosurfactantproducing bacteria-Product characterization, and evolution. Acta Biotecnologica, Berlin 2, 315-324.

Brown, M.J. (1991), Biosurfactants for cosmetic applications. International Journal of Cosmetic Science . 13, 61-64.

Casas, J.A. (1996), Producción de soforolípidos por Candida bombicola. Tese phD - Universidad Complutense, Madri.

Cameotra, S.S. and Makkar, R.S. (1998), Synthesis of biosurfactants in extreme conditions. Applied Microbiology and Biotechnology . 50, 520-529.

Cirigliano, M.C. and Carman, G.M. (1985), Purification and characterization of liposan a bioemulsier from Candida lipolytica. Applied and Environmental Microbiology. Washington. 50, 846-850.

Cirigliano, M.C. and Carman, G.M. (1984), Isolation of a bioemulsifier from Candida lipolytica. Applied and Environmental Microbiology. 48, 747-750.

Cooper, D.G. and Goldenberg, B.G. (1987), Surface active agents from two Bacillus species. Applied Enviromental Microbiology. 53, 224-229.
Davila, A.M.; Marchal, R. and Vandecastele, J.P. (1992), Kinetics and balance of a fermentation free from product inhibition: sophorose lipid production by Candida bombicola. Applied Microbiology and Biotechnology. 38 6-11.

Desai J.D. and Banat, I.M. (1997), Microbial production of surfactants and their commercial potential. Microbial Molecular Reviews. 61, 47-64.

Deleu, M. and Paquot, M. (2004), From renewable vegetables resources to microorganisms: new trends in surfactants Compters Rendus Chimie. (article in press).

Dubey, K. and Juwarkar, A. (2001), Destillery and curd whey wastes as viable alternative sources for biosurfactants production. World Journal of Microbiology and Biotechnology. 17, 61-69.

Garcia-Ochoa, F. and Casas, J.A. (1999), Unstructured kinetic model for sophorolipid production by Candida bombicola. Enzyme and Microbial Technology. 25, 613-621.

Gallert, C. and Winter, J. (2002), Solid and liquid residues as raw materials for biotechnology. Zeitschrift fur Naturforschung. 89, 483-496.

Gerson, D. F.(1993), Biosurfactants: produtionproperties - applications. In: Biotechnology.

Gomes, P.F.; Nascimento, A.E.; Okada, K.; Messias, A.S.; Sharia, A.E.N. and Campos-TakakiI, G.M. (2000), Aspectos da qualidade de ecossistemas do Município do Rio Formoso. In: International Conference: Sustainable use of estuaries and mangroves: challenges and prospects. Abstracts, $\mathrm{p}$. 82.

Ghurye, G. L.; Vipulananda, C. and Wilson, R. C. A. (1994), Practical approach to biosurfactant production using nonaseptic fermantation of mixed cultures. Biotechnology and Bioengineering. 44, 661-666.

Hanson, R.S.; Phillips, J.A. and Gherhardt, P. (1981), Manual of Methods for General Bacteriology, American Society for Microbiology, Washington, DC. 328-364.

Hua, Z.; Chen, J.; Lun, S. and Wang, X. (2003), Influence of biosurfactants produced by Candida antarctica on surface properties of microorganism and biodegradation of n-alkanes. Water Research. 37, 4143-4150.

Kim, S.H.; Lim, E.J.; Lee,S.O.; Lee, J.D. and Lee, T.H. (2000), Purification and characterization of biosurfactants from Nocardia sp. L - 417. Biotechnology and Applied Biochemistry. 31, 249253.

Kuyukina, M.S.; Ivshina, I.B.; Philp, J.C.; Christofi, N.; Dunbar, S.A. and Ritchkova, MI. (2001), Recovery of Rhodococcus biosurfactants using methyl tertiarybutyl rther extraction. Journal of Microbiological Methods. 46, 109-120. 
Lang, S.; Katsiwala, E. and Wagner F. (1989), Antimicrobial effects of biosurfactants. Fat Science and Technology. 9, 363-366.

Lowry, O.H.; Rosenbrough, N.J.; Farr, A.L. and Randall, R.J. (1951), Protein measurement with the folin phenol reagent. Journal of Biological Chemistry. 193, 265-275.

Manocha, M.S., San-Blas, G. and Centeno, S. (1980), Lipid composition of Paracoccidioides brasilienses: possible correlation with virulence of different strains. Journal of General Microbiology. 117, 147154.

Makkar, R.S and Cameotra, S.S. (1998), Production of biosurfactant at mesophilic and thermophilic conditions by a strain of Bacillus subtillis. Journal of Microbiology and Biotechnology. 20, 48-52.

Makkar, R.S. and Cameotra, S.S. (2002), An update on the use of uncoventional substrates for biosurfactant production and their new applications. Applied and Environmental Microbiology. 58, 428.

Marín, M. and Pedregosa, A . (1996), International. Biodeterioration and Biodegradation. 69-75.

Mercadé., M.E.; Moneon, L.; de Andes, C.; Rondon, I., Martinez, E.; Espuny, M.J. and Manresa, A. (1996), Screening and selection of surfactant- producing bacteria from waste lubrificating oil. Journal applied Bacteriology. 8, 161-168.

Mercade, M.E.; Manresa, M.A.; Robert, M.; Espuny, C. and Guinea, J. (1993), Olive oil mill efluent (OOME) new substrate for biosurfactant production. Bioresource Technology. 43, 1-6.

Nascimento, R.M.L; Pimentel, A. C.M.; Araújo, S.F.S.; Okada, k.; Nascimento, A.E.; Alves da Silva.; C.A and Campos Takaki, G.M. (2000), Symposium 56-59.

Nitschke, M. and Pastore, G.M. (2002), Biosurfactantes: propriedades e aplicações. Química Nova. 25, 772-776.

Pareilleux, A. (1979), Hydrocarbon assimilation by Candida lipolytica: formation of a biossufactant, effects on respiratory activity and growth. Europen.. Journal of Applied Microbiology and Biotechnology, Berlin. 8, 91-101.

Paraszkiewicz, K.; Kanwal, A. and Dlugonski, J. (2002), Emulsifier production by steroid transforming filamentous fungus Curvularia lunata. Growth and product characterization. Journal of Biotechnology. 92, 287-294.

Pirt, S. J. (1975), Principles of microbe and cell cultivation. London: Blackwell Scientific. 214-215.

Queiroga, C.L.; Nascimento, L.R. and Serrra, G.E. (2003), Evalution of paraffins biodegradation and biossurfactant production by Bacillus subtilis in the presence of crude oil. Brazilian Journal of Microbiology . 34, 1321-324.
Rahman, K.S.M.; Rahman, T.J.; Kourkoutas, Y.; Petsas, I., Marchant, R and Banat, I.M. (2003), Enhanced bioremediation of $\mathrm{n}$ - alkanes in petroleum sludge using bacterial consortium amended with rhamnolipid and micronutrients. Bioresouce Technology. 90, 159-168

Ron, E.Z. and Rosenberg, E. (2001), Natural roles of biosurfactants, Zeitschrift fur Naturforschung. 3, 229-236.

Sarubbo, L.A.; Marcel M.C.R. and Campos-Takaki G.M. (1997), Comparative study on bioemulsifiers produced by Candida lipolylica strains. Brazilian Archives of Biology and Technolog. 40, 707-720.

Sarubbo, L. A.; Porto, A.L.F. and Campos-Takaki, G.M.(1999), The use of babassu oil as substrate to produce bioemulsifiers by Candida lipolytica. Canadian Journal of Microbiology. 45, 423-426.

Sarubbo, L.A.; Marçal, M.C.; Neves, M.L.C.; Silva, M.P.C.; Porto, A.L.F. and Campos-Takaki, G.M. (2001), Bioemulsifier production in batch culture using glucose as carbon source by Candida lipolytica. Applied Biochemistry and Biotechnology. 95, 59-67.

Sarubbo, L.A.; Luna, J.M.; and Campos-Takaki, G.M.(2006), Production and stability studies of the bioemulsifier obtained from a new strain of Candida glabrata UCP 1002. Eletronic Journal of Biotechnology.

Soon, E.L.; Salleh, A.B.; Basri, M.; Rahman, R.N. and Kamaruddin, K. (2004), Response surface methodological study on lipase-catalyze synthesis of amino acid surfactants. Process Biochemistry 39, 1511-1518.

Vollbrecht E.; Rau U. and Lang S. (1999), Microbial conversion of vegetable oils into surface-active ditri-, and tetrasaccharide lipids (biosurfactants) by the bacterial strain Tsukamurella spec.Fet/Lipd 101, 389394.

Zhou, Q. H. and Kosaric, N. (1993), Effect of lactose and olive oil on intra- and extracellular lipids of Torulopsis bombicola. Biotechnology Letters 15, 477482.

Zhou, Q.H. and N. Kosaric. (1995), Utilization of Canola Oil and lactose to produce biosurfactant with Candida bombicola. Journal of American Oil and Chemistry Society. 72, p. 67-71.
Received: July 24, 2006; Revised: October 25, 2007; Accepted: July 21, 2008. 